\title{
Mikrostruktura i właściwości stali o wysokiej wytrzymałości AHSS
}

\author{
Microstructure and mechanical properties \\ of Advanced High - Strength Steels (AHSS)
}

\section{Streszczenie}

Przedstawiono nowe stale o wysokiej wytrzymałości AHSS na podstawie analizy danych źródłowych. Zaprezentowano składy chemiczne i właściwości mechaniczne wybranych gatunków tych stali.

Stale o wysokiej wytrzymałości coraz częściej używane są w przemyśle motoryzacyjnym oraz w budowie ciężkich maszyn. Właściwości mechaniczne i ciągliwość tych stali pozwalają na projektowanie lżejszych i bardziej wytrzymałych konstrukcji o dotąd nieosiągalnych możliwościach. Spawalność stali AHSS jest dobra. Dzięki prostemu składowi chemicznemu i małej liczbie dodatków stopowych możliwość doboru metody i parametrów spawania jest szeroka i dotyczy zarówno zgrzewania, jak i spawania metodami MMA, GTA i GMA.

\section{Abstract}

The characteristic of this novel group of steels is done on literature source bases. Chemical composition and mechanical properties of representatives of different groups of these steels is presented. Advanced High-Strength Steels are increasingly used in the automotive industry and in the construction of heavy machines. The mechanical properties and toughness of these steel permit to design lighter and high strength structures with previously unattainable possibilities. Weldability of these steels is defined as a good. Due to a plain chemical composition and small amount of alloying elements, possibility of welding method and parameters selection is large and allow use well known resistance spot welding as well as MMA, GTA and GMA methods.

\section{Wstęp}

Wyjątkowe właściwości mechaniczne stali o wysokiej wytrzymałości AHSS (AHSS - Advanced High -Strength Steel) są efektem umocnienia w wyniku przemian fazowych w zakresie temperatur wspótistnienia ferrytu i przechłodzonego austenitu w warunkach odkształcenia plastycznego lub szybkiego chłodzenia $z$ austenitu w celu utworzenia struktury martenzytycznej.

Stale AHSS stały się szczególnie atrakcyjne w produkcji pojazdów z trzech ważnych powodów:

- dużej wytrzymałości na rozciąganie, do $1700 \mathrm{MPa}$,

- dużej granicy plastyczności, do $1450 \mathrm{MPa}$,

- dużego wydłużenia $\mathrm{A}_{80}$, do $30 \%$.

Stale o wysokiej wytrzymałości stosunkowo łatwo poddają się obróbce plastycznej i obróbce skrawaniem.

Mgr inż. Sławomir Krajewski, prof. dr hab. inż. Jerzy Nowacki - Zachodniopomorski Uniwersytet Technologiczny w Szczecinie.
Wzrost zastosowania nowoczesnych stali AHSS w przemyśle motoryzacyjnym wynika z możliwości zmniejszenia grubości blach karoseryjnych $z$ jednoczesnym polepszeniem właściwości mechanicznych konstrukcji w porównaniu z zastosowaniem konwencjonalnych stali.

Zastosowanie stali AHSS powoduje zmniejszenie masy konstrukcji oraz mniejsze zużycie energii na jej wytworzenie. Stale o wysokiej wytrzymałości znajdują zastosowanie nie tylko w produkcji pojazdów, ale także urządzeń dźwigowych, wysięgników maszyn, urządzeń przeładunkowych do transportu morskiego, maszyn budowlanych i ram wózków kolejowych. Istotną zaletą tej grupy stali jest również ich umiarkowana cena wynikająca z małej liczby dodatków stopowych, możliwość zmniejszenia przekrojów konstrukcji oraz dobre właściwości technologiczne, w tym spawalność i skrawalność.

Te cechy stali AHSS powodują wzrost ich udziału szczególnie w produkcji pojazdów, gdzie ich masa może być zmniejszona nawet o $25 \%$. Geneza rozwoju badań prowadzonych nad stalami AHSS wynika z konieczności zwiększenia wytrzymałości i sztywności 
kluczowych elementów pojazdu mających wpływ na bezpieczeństwo pasażera. Przemiana austenitu szczątkowego w martenzyt podczas odkształcania stali powoduje pochłanianie energii kinetycznej, co ma znaczenie w przypadku kolizji drogowych $[1 \div 4]$.

\section{Mikrostruktura i właściwości stali o wysokiej wytrzymałości}

Stale AHSS swoją wytrzymałość zawdzięczają połączeniu zróżnicowanych faz, takich jak bainit, ferryt, martenzyt i austenit szczątkowy. Wielofazowe stale AHSS pozostają plastyczne pomimo obecności w nich martenzytu i/lub bainitu. Każda faza ma określone właściwości fizyczne i mechaniczne wynikające z sił działających pomiędzy atomami w kryształach.

Pierwszym etapem procesu obróbki stali jest odkształcenie plastyczne w wyniku walcowania na gorąco (w przypadku stali CP i MART) w temperaturze trwałości austenitu $\left(850^{\circ} \mathrm{C}\right)$ lub walcowanie na zimno (w przypadku stali DP i TRIP). Drugim etapem procesu jest walcowanie z kontrolowanym chłodzeniem. W produkcji stali MART od razu po walcowaniu blach na gorąco przeprowadzane jest hartowanie martenzytyczne.

Proces technologiczny stosowany do obróbki w linii produkcyjnej polega na ciągłym walcowaniu na gorąco stali w zakresie występowania czystego austenitu, a następnie bardzo szybkim chłodzeniu wodą. W przypadku dalszego wyżarzania kontrolowany jest stosunek ilości względnej austenitu i ferrytu.

W celu otrzymania mikrostruktury stali DP przeprowadzane jest gwałtowne chłodzenie z temperatury austenityzacji, aby nie zaszła dalsza przemiana powodująca pojawienie się bainitu bądź perlitu. Wskutek tego zachodzi przemiana austenitu w martenzyt. Stale te produkowane są przez kontrolowane chłodzenie z fazy austenitu (z wyrobów walcowanych na gorąco) albo ze stali ferrytyczno-austenitycznych (wyżarzanych i walcowanych na zimno, a następnie wysoko odpuszczanych).

W celu uzyskania struktury trójskładnikowej - typowej dla stali $\mathrm{CP}$, wyżarzanie realizowane jest tak, aby z pozostałego austenitu częściowo wytworzyć strukturę bainityczną, a częściowo martenzytyczną. Otrzymana struktura ma lepsze właściwości mechaniczne, między innymi z powodu drobnoziarnistości.

Produkcja stali TRIP przebiega podobnie jak stali $\mathrm{CP}$, lecz podczas ostatniej przemiany zachowane są warunki dla przebiegu przemiany izotermicznej w celu dalszego rozdrobnienia ziarna i stabilizacji austenitu w wyniku wzbogacania go w węgiel. Zapewnia to stabilność mikrostruktury w temperaturze pokojowej. Składniki stopowe: mangan, chrom, aluminium, bor, krzem i molibden ułatwiają przechodzenie przemian podczas chłodzenia. Wymienione przemiany przedstawiono na rysunku 1.

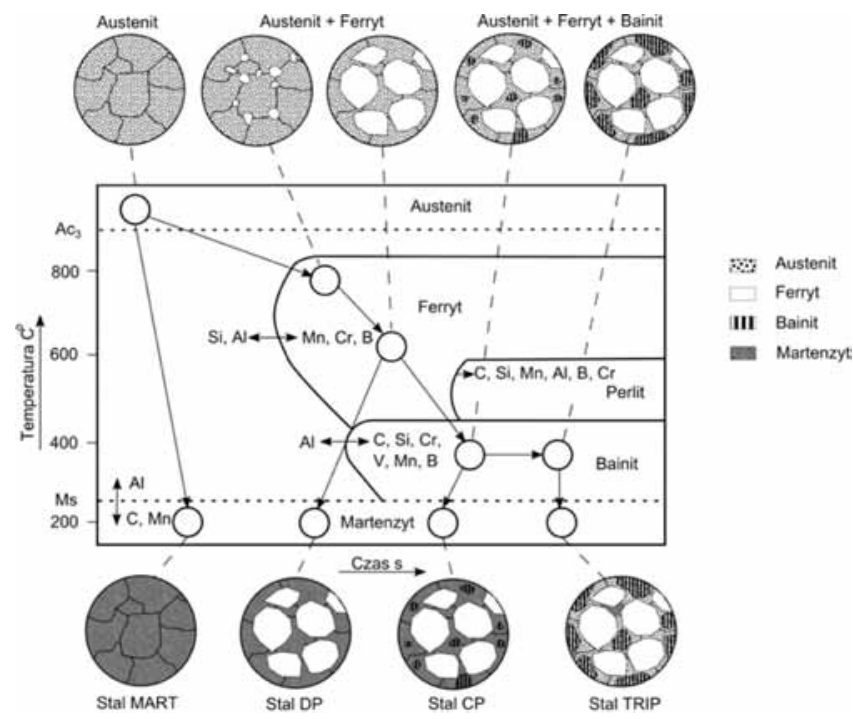

Rys. 1. Schemat przemian fazowych przy chłodzeniu stali. Opracowanie własne na podstawie [5]

Fig. 1. Diagram of phase transition during the steel cooling. Own work on the basis of [5]

\section{Podstawowe grupy stali o wysokiej wytrzymałości}

W grupie stali o wysokiej wytrzymałości można wy-

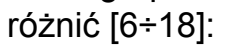

- stale martenzytyczne - MART,

- stale dwufazowe - DP,

- stale complex - CP,

- stale z efektem TRIP.

Stale martenzytyczne MART są stalami konstrukcyjnymi niskostopowymi, walcowanymi na zimno. Charakteryzują się bardzo wysoką granicą plastyczności i wytrzymałością na rozciąganie. Wydłużenie względne jest wystarczające do kształtowania na zimno. Do spajania blach ze stali martenzytycznej można używać tych samych metod łączenia jak dla standardowych blach stalowych, dzięki małej ilości dodatków stopowych przy zachowaniu dużej wytrzymałości. Obecnie najbardziej wytrzymałą stalą konstrukcyjną jest stal Optim 1500 QC Ruukki. Ta niezwykła stal ma też dobrą odporność na ścieranie i korozję. W swojej ofercie Ruukki oferuje blachy pancerne Ramor, które zapewniają maksymalną ochronę i bezpieczeństwo dzięki dużej twardości i wytrzymałości.

Stale o wysokiej wytrzymałości stosuje się na tarcze sprzęgła, narzędzia tnące, sejfy bankowe, noski i podeszwy na obuwie ochronne, sprzęt wojskowy opancerzony oraz elementy zwiększające bezpieczeństwo w autach. W tablicy I przedstawiono skład chemiczny, a w tablicy II właściwości mechaniczne stali martenzytycznych różnych producentów.

Stale dwufazowe DP (Dual-Phase Steel) mają osnowę ferrytyczną z wtrąceniami martenzytu, jed-

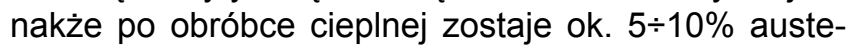
nitu szczątkowego, który jest metastabilny. Nadaje on stali skłonność do umocnienia podczas pracy (ruchy 
Tablica I. Skład chemiczny wybranych stali martenzytycznych MART

Table I. Chemical composition of selected martensitic steels (MART)

\begin{tabular}{|c|c|c|c|c|c|c|c|c|c|c|c|c|}
\hline \multirow{2}{*}{ Stal } & \multicolumn{12}{|c|}{ Skład chemiczny, \% } \\
\hline & $C$ & $\mathrm{Si}$ & $\mathrm{Mn}$ & $P$ & $S$ & $\mathrm{Ti}$ & $\mathrm{Cr}$ & $\mathrm{Al}$ & $\mathrm{Nb}$ & $B$ & $\mathrm{Ni}$ & Mo \\
\hline Docol 900M & 0,05 & 0,20 & 2,00 & 0,010 & 0,002 & 0 & 0 & 0,04 & 0 & 0 & 0 & 0 \\
\hline Docol 1000DPZE & 0,15 & 0,50 & 1,50 & 0,010 & 0,002 & 0 & 0 & 0,04 & 0,015 & 0 & 0 & 0 \\
\hline Docol 1100M & 0,09 & 0,20 & 1,70 & 0,010 & 0,002 & 0,025 & 0 & 0,04 & 0,015 & 0 & 0 & 0 \\
\hline Docol 1200M & 0,11 & 0,20 & 1,70 & 0,010 & 0,002 & 0,025 & 0 & 0,04 & 0,015 & 0 & 0 & 0 \\
\hline Docol 1300M & 0,20 & 0,20 & 1,50 & 0,010 & 0,002 & 0,025 & 0 & 0,04 & 0,015 & 0 & 0 & 0 \\
\hline Docol 1400M & 0,17 & 0,20 & 1,40 & 0,010 & 0,002 & 0,025 & 0 & 0,04 & 0,015 & 0 & 0 & 0 \\
\hline Docol 1500M & 0,21 & 0,20 & 1,10 & 0,010 & 0,002 & 0,025 & 0 & 0,04 & 0,015 & 0 & 0 & 0 \\
\hline Docol 900MZE & 0,05 & 0,20 & 1,90 & 0,010 & 0,002 & 0,000 & 0 & 0,04 & 0 & 0 & 0 & 0 \\
\hline Docol 1200MZE & 0,11 & 0,20 & 1,70 & 0,010 & 0,002 & 0,035 & 0 & 0,04 & 0 & 0,002 & 0 & 0 \\
\hline Docol 1400MZE & 0,17 & 0,20 & 1,40 & 0,010 & 0,002 & 0,035 & 0 & 0,04 & 0 & 0,002 & 0 & 0 \\
\hline Docol 1500MZE & 0,21 & 0,20 & 1,10 & 0,010 & 0,002 & 0,035 & 0 & 0,04 & 0 & 0,002 & 0 & 0 \\
\hline MS-W 1200 & 0,18 & 0,80 & 2,00 & 0,020 & 0,010 & 0,050 & 1 & 0 & 0,1 & 0 & 0 & 0 \\
\hline Optim 900 QC & 0,10 & 0,25 & 1,15 & 0,020 & 0,010 & 0,070 & 0 & 0 & 0 & 0 & 0 & 0 \\
\hline Optim 960 QC & 0,11 & 0,25 & 1,20 & 0,020 & 0,010 & 0,070 & 0 & 0 & 0 & 0 & 0 & 0 \\
\hline Optim 1100 QC & 0,15 & 0,30 & 1,25 & 0,020 & 0,010 & 0,070 & 0 & 0 & 0 & 0 & 0 & 0 \\
\hline Raex 300 & 0,18 & 0,70 & 1,70 & 0,025 & 0,015 & 0 & 1,5 & 0 & 0 & 0,005 & 0,4 & 0,5 \\
\hline Raex 400 & 0,25 & 0,70 & 1,70 & 0,025 & 0,015 & 0 & 1,5 & 0,06 & 0 & 0,005 & 0,7 & 0,5 \\
\hline Raex 450 & 0,26 & 0,70 & 1,70 & 0,025 & 0,015 & 0 & 1 & 0,06 & 0 & 0,005 & 0,7 & 0,5 \\
\hline Raex 500 & 0,30 & 0,70 & 1,70 & 0,025 & 0,015 & 0 & 1 & 0,06 & 0 & 0,005 & 0,8 & 0,5 \\
\hline Ramor 400 & 0,24 & 0,70 & 1,50 & 0,020 & 0,015 & 0 & 1 & 0 & 0 & 0,005 & 1 & 0,7 \\
\hline Ramor 500 & 0,32 & 0,70 & 1,50 & 0,020 & 0,015 & 0 & 1 & 0 & 0 & 0,005 & 2 & 0,7 \\
\hline SZMS1200 & 0,18 & 0,15 & 2,00 & 0,020 & 0,010 & 0 & 0,6 & 0,02 & 0 & 0 & 0 & 0 \\
\hline
\end{tabular}

Tablica II. Właściwości mechaniczne wybranych stali martenzytycznych MART

Table II. Mechanical properties of selected martensitic steels (MART)

\begin{tabular}{|l|c|c|c|c|c|}
\hline \multirow{2}{*}{ Stal } & \multicolumn{5}{|c|}{ Właściwości mechaniczne } \\
\cline { 2 - 6 } & $\begin{array}{c}\mathrm{R}_{\text {e min }} \\
\text { MPa }\end{array}$ & $\begin{array}{c}\mathrm{R}_{\text {e max }} \\
\mathrm{MPa}\end{array}$ & $\begin{array}{c}\mathrm{R}_{\mathrm{m} \text { min }} \\
\mathrm{MPa}\end{array}$ & $\begin{array}{c}\mathrm{R}_{\text {m max }} \\
\mathrm{MPa}^{*}\end{array}$ & $\begin{array}{c}\mathrm{A}_{80} \\
\%\end{array}$ \\
\hline Docol 900M & 700 & 1000 & 900 & 1100 & 6 \\
\hline Docol 1000DPZE & 700 & 950 & 1000 & 1200 & 7 \\
\hline Docol 1100M & 860 & 1100 & 1100 & - & 5 \\
\hline Docol 1200M & 950 & 1150 & 1200 & 1400 & 3 \\
\hline Docol 1300M & 1030 & 1300 & 1300 & - & 3 \\
\hline Docol 1400M & 1150 & 1350 & 1400 & 1600 & 3 \\
\hline Docol 1500M & 1200 & 1500 & 1500 & 1700 & 3 \\
\hline Docol 900MZE & 700 & - & 900 & 1100 & 3 \\
\hline Docol 1200MZE & 950 & - & 1200 & 1400 & 3 \\
\hline Docol 1400MZE & 1150 & - & 1400 & 1600 & 3 \\
\hline Docol 1500MZE & 1200 & - & 1500 & 1700 & 3 \\
\hline MS-W 1200 & 900 & - & 1200 & 1400 & 5 \\
\hline Optim 900 QC & 900 & 1000 & 1050 & 1150 & 11 \\
\hline Optim 960 QC & 960 & 1060 & 1080 & 1180 & 10 \\
\hline Optim 1100 QC & 1100 & 1200 & 1280 & 1380 & 8 \\
\hline Optim 1500 QC & 1460 & - & 1650 & 1850 & 5 \\
\hline Raex 300 & 900 & - & 1000 & - & 11 \\
\hline Raex 400 & 1000 & - & 1250 & - & 10 \\
\hline Raex 450 & 1200 & - & 1450 & - & 8 \\
\hline Raex 500 & 1250 & - & 1600 & - & 8 \\
\hline Ramor 400 & 1100 & - & 1300 & - & 8 \\
\hline Ramor 500 & 1450 & - & 1700 & - & 7 \\
\hline SZMS1200 & 1050 & 1200 & 1450 & 5 \\
\hline Opracowanie własne na podstawie danych producentów & & \\
\hline
\end{tabular}

dyslokacji w krystalicznej strukturze metalu). W jednej fazie ferryt zapewnia formowalność, a w drugiej fazie martenzyt $(20 \div 70 \%)$ zwiększa wytrzymałość. Stale dwufazowe mają umowną granicę plastyczności sięgającą $800 \mathrm{MPa}$. Na początku procesu formowania umacniają się najbardziej i granica ta może osiągnąć $1000 \mathrm{MPa}$. W miejscach odkształceń rozszerzają się obszary występowania martenzytu, polepszając właściwości stali. Prędkość odkształcenia i duże wydłużenie względne nadaje stali DP większą wytrzymałość niż konwencjonalnym stalom o podobnej plastyczności. Naprężenia wewnętrzne niwelowane są przez umacnianie drugiej fazy w martenzyt, co powoduje niższy stosunek $R_{e} / R_{m}$. Podczas zderzenia energia jest lepiej pochłaniana przez materiał i są mniejsze skutki odkształceń. Stale DP wskutek ubogiej zawartości pierwiastków stopowych charakteryzują się dobrą spawalnością, są dobrze formowalne na zimno; podczas walcowania czy operacji gięcia zaleca się przeprowadzać je poprzecznie do kierunku walcowania.

Stale te znajdują zastosowanie jako rury w wózkach dziecięcych lub ramach od rowerów, zwiększają także bezpieczeństwo w samochodach, gdzie wykonywane z nich są wzmocnienia zderzaków i prowadnice foteli, fotelików dziecięcych, słupki drzwiowe i koła. Dzięki wysokiej wytrzymałości oraz dużej twardości wpływającej na odporność na ścieranie, wykonywane są z nich również: tarcze sprzęgła, maszyny do cięcia żywopłotów, noże, łańcuchy na piły.

W stalach DP stosuje się dodatki stopowe takie jak: mangan, chrom, molibden i nikiel, które zwiększają hartowność stali. Zwiększając udział węgla, zwiększa się ilość martenzytu. Od zawartości krzemu i fosforu 
Tablica III. Skład chemiczny wybranych stali dwufazowych DP

Table. III. Chemical composition of selected dual-phase steels (DP)

\begin{tabular}{|c|c|c|c|c|c|c|c|c|c|c|c|c|}
\hline \multirow{2}{*}{ Stal } & \multicolumn{12}{|c|}{ Skład chemiczny, \% } \\
\hline & C & $\mathrm{Si}$ & $\mathrm{Mn}$ & $\mathrm{P}$ & $\mathrm{S}$ & $\mathrm{Cr}$ & $\mathrm{Al}$ & $\mathrm{Nb}$ & V & $B$ & Cr-Mo & $\mathrm{Nb}-\mathrm{Ti}$ \\
\hline Docol 450DP & 0,05 & 0,20 & 1,50 & 0,01 & 0,002 & 0 & 0,04 & 0 & 0 & 0 & 0 & 0 \\
\hline Docol 500DP & 0,08 & 0,30 & 0,65 & 0,01 & 0,002 & 0 & 0,04 & 0 & 0 & 0 & 0 & 0 \\
\hline Docol 600DP & 0,10 & 0,20 & 0,80 & 0,01 & 0,002 & 0 & 0,04 & 0,015 & 0 & 0 & 0 & 0 \\
\hline Docol 780DP & 0,14 & 0,20 & 1,50 & 0,01 & 0,002 & 0 & 0,04 & 0,015 & 0 & 0 & 0 & 0 \\
\hline Docol 800DP & 0,13 & 0,20 & 1,50 & 0,01 & 0,002 & 0 & 0,04 & 0,015 & 0 & 0 & 0 & 0 \\
\hline Docol 980DP & 0,15 & 0,50 & 1,50 & 0,01 & 0,002 & 0 & 0,04 & 0,015 & 0 & 0 & 0 & 0 \\
\hline Docol 1000DP & 0,15 & 0,50 & 1,50 & 0,01 & 0,002 & 0 & 0,04 & 0,015 & 0 & 0 & 0 & 0 \\
\hline Docol 1180DP & 0,15 & 0,50 & 1,50 & 0,01 & 0,002 & 0 & 0,04 & 0,015 & 0 & 0 & 0 & 0 \\
\hline Dogal 800 DPX & 0,16 & 0,25 & 1,90 & 0,02 & 0,004 & 0,6 & 0,02 & 0 & 0 & 0 & 0 & 0 \\
\hline Dogal 1000 DPX & 0,20 & 0,25 & 1,90 & 0,02 & 0,004 & 0,4 & 0,02 & 0 & 0,02 & 0,001 & 0,8 & 0,03 \\
\hline DP-K 30/50 & 0,10 & 0,30 & 1,80 & 0,04 & 0,010 & 0 & 0,1 & 0 & 0 & 0,005 & 1 & 0,15 \\
\hline DP-K 34/60 & 0,14 & 0,50 & 2,00 & 0,04 & 0,010 & 0 & 1,5 & 0 & 0 & 0,005 & 1 & 0,15 \\
\hline DP-K 34/60 HF & 0,14 & 0,30 & 2,00 & 0,04 & 0,010 & 0 & 1,5 & 0 & 0 & 0,005 & 1 & 0,15 \\
\hline DP-K 45/78 & 0,18 & 0,50 & 2,20 & 0,04 & 0,010 & 0 & 1,2 & 0 & 0 & 0,005 & 1 & 0,15 \\
\hline DP-K 60/90 & 0,20 & 0,60 & 2,50 & 0,04 & 0,010 & 0 & 1,2 & 0 & 0 & 0,005 & 1 & 0,15 \\
\hline DP-W 600 & 0,12 & 0,80 & 1,50 & 0,06 & 0,010 & 0 & 0,08 & 0 & 0 & 0,005 & 1 & 0,15 \\
\hline DP-W 700 & 0,12 & 0,80 & 1,50 & 0,06 & 0,010 & 0 & 0,08 & 0 & 0 & 0,005 & 1 & 0,15 \\
\hline НСT600 & 0,17 & 0,80 & 2,20 & 0,08 & 0,015 & 0 & 2 & 0 & 0,2 & 0,005 & 1 & 0,15 \\
\hline Litec 600 DP & 0,17 & 0,80 & 2,20 & 0,01 & 0,002 & 0 & 2 & 0 & 0 & 0 & 1 & 0,15 \\
\hline Litec 800 DP & 0,18 & 0,80 & 2,50 & 0,01 & 0,002 & 0 & 2 & 0 & 0 & 0 & 1 & 0,15 \\
\hline Litec 1000 DP & 0,23 & 0,80 & 2,50 & 0,01 & 0,002 & 0 & 2 & 0 & 0 & 0 & 1 & 0,15 \\
\hline
\end{tabular}

Tablica IV. Właściwości mechaniczne wybranych stali dwufa zowych DP

Table IV. Mechanical properties of selected dual-phase steels (DP)

\begin{tabular}{|l|c|c|c|c|c|}
\hline \multirow{2}{*}{\multicolumn{1}{|c|}{ Stal }} & \multicolumn{5}{|c|}{ Właściwości mechaniczne } \\
\cline { 2 - 6 } & $\begin{array}{c}\mathrm{R}_{\text {e min }} \\
\text { MPa }\end{array}$ & $\begin{array}{c}\mathrm{R}_{\text {e max }} \\
\text { MPa }\end{array}$ & $\begin{array}{c}\mathrm{R}_{\mathrm{m} \text { min }} \\
\text { MPa }\end{array}$ & $\begin{array}{c}\mathrm{R}_{\mathrm{m} \max } \\
\text { MPa }\end{array}$ & $\begin{array}{c}\mathrm{A}_{80} \\
\%\end{array}$ \\
\hline Docol 450DP & 260 & 330 & 450 & 550 & 27 \\
\hline Docol 500DP & 300 & 370 & 500 & 600 & 24 \\
\hline Docol 600DP & 340 & 410 & 600 & 700 & 21 \\
\hline Docol 780DP & 450 & 560 & 780 & 900 & 15 \\
\hline Docol 800DP & 500 & 640 & 780 & 950 & 10 \\
\hline Docol 980DP & 600 & 750 & 980 & 1100 & 10 \\
\hline Docol 1000DP & 700 & 950 & 1000 & 1200 & 8 \\
\hline Docol 1180DP & 830 & 1220 & 1180 & - & 6 \\
\hline Dogal 800 DPX & 620 & 770 & 800 & 950 & 10 \\
\hline Dogal 1000 DPX & 800 & 1000 & 1000 & 1200 & 6 \\
\hline DP-K 30/50 & 300 & 370 & 500 & 600 & 24 \\
\hline DP-K 34/60 & 340 & 410 & 600 & 700 & 20 \\
\hline DP-K 34/60 HF & 340 & 410 & 600 & 700 & 23 \\
\hline DP-K 45/78 & 450 & 780 & 780 & 900 & 14 \\
\hline DP-K 60/90 & 600 & 750 & 980 & 1120 & 10 \\
\hline DP-W 600 & 330 & 460 & 580 & 680 & 19 \\
\hline DP-W 700 & 450 & 580 & 680 & 800 & 16 \\
\hline HCT600 & 340 & 420 & 600 & 700 & 20 \\
\hline Litec 600 DP & 340 & 420 & 600 & - & 18 \\
\hline Litec 800 DP & 450 & 560 & 780 & - & 12 \\
\hline Litec 1000 DP & 600 & 750 & 980 & - & 8 \\
\hline Opracowanie własne na podstawie danych producentów & \\
\hline & & & & & \\
\hline
\end{tabular}

zależy podatność stali na zgrzewanie oporowe i spawalność - brak pęknięć. Stale DP o najwyższych właściwościach mechanicznych mogą wymagać zmiany technologii spajania termicznego. W tablicy III przedstawiono skład chemiczny, a w tablicy IV właściwości mechaniczne stali Dual-Phase różnych producentów.

Stale complex CP (Complex-Phase Steel) maja granicę na rozciąganie do $1000 \mathrm{MPa}$. Stale te są integralną częścią nowej generacji zaawansowanych stali o wysokiej wytrzymałości używanych w przemyśle motoryzacyjnym. Absorbują więcej energii niż już omówione, są mniej podatne na odkształcenia, wykazują się wytrzymałością resztkową po obciążeniu udarowym. Mikrostruktura podobna jest do mikrostruktury stali TRIP z wyjątkiem występowania austenitu. Stale CP składają się z drobnoziarnistych ziaren ferrytu, umacnianych przez bainit i martenzyt. Stale te mają mniejsze ilości dodatków stopowych takich jak niob, tytan i wolfram. Stal może być dodatkowo utwardzana wydzieleniowo.

Stale te sa stosowane do budowy zderzaków jako wzmocnienie właściwe, na którym są osadzane przekładki styropianowe i okładziny z tworzywa sztucznego. Dzięki wytrzymałości resztkowej stali i elastycznych tworzyw sztucznych doskonale absorbują energię kolizji. $\mathrm{W}$ tablicy $\mathrm{V}$ przedstawiono skład chemiczny, a w tablicy VI właściwości mechaniczne stali complex - phase różnych producentów.

Stale $\mathbf{z}$ efektem TRIP. Struktura stali opiera się na osnowie ferrytu z niestabilnym austenitem szczątkowym (> 5\%) oraz kompozycji twardych struktur bainitu i martenzytu w różnych ilościach - co jest wynikiem innej obróbki cieplnej. Struktura wielofazowa zapewnia równowagę właściwości wytrzymałościowych 
i plastycznych. Ilość austenitu szczątkowego w końcowej mikrostrukturze można regulować zawartością manganu, aluminium i węgla. Efektem TRIP jest umocnienie ferrytu martenzytem tworzącym się z austenitu szczątkowego pod wpływem energii powodującej odkształcenie plastyczne. Umocnienie się stali ma charakter długofalowy w całym zakresie odkształceń plastycznych.

Efekt TRIP zależy od stabilności austenitu szczątkowego. Jeśli zawartość węgla jest niska, to przemiana następuje natychmiast, bez dużych odkształceń podczas formowania. W przemyśle motoryzacyjnym potrzebne są materiały na detale podatne na tłoczenie, jednocześnie dobrze spawalne i zgrzewalne.
W rzeczywistości kierowanie się zawartością węgla jest największym problemem. Stale TRIP mogą być zaprojektowane z myślą o konkretnym elemencie, który będzie formowany z arkusza, bądź taśmy stalowej. Taki element jest podatny na formowanie metodą obróbki plastycznej (dzięki większej zawartości węgla stal jest stabilna podczas tłoczenia), co umożliwia otrzymanie skomplikowanych kształtów bez ubytku możliwości do późniejszej TRIP (Transformacji Indukowanej Plastycznością).

W tablicy VII przedstawiono skład chemiczny, a $w$ tablicy VIII właściwości mechaniczne stali z efektem TRIP różnych producentów.

Tablica V. Skład chemiczny wybranych stali complex CP

Table V. Chemical composition of selected complex-phase steels (CP)

\begin{tabular}{|c|c|c|c|c|c|c|c|c|c|c|c|}
\hline \multirow{2}{*}{ Stal } & \multicolumn{11}{|c|}{ Skład chemiczny, \% } \\
\hline & C & $\mathrm{Si}$ & $\mathrm{Mn}$ & $\mathrm{P}$ & S & $\mathrm{Cr}$ & $\mathrm{Al}$ & V & B & Cr-Mo & $\mathrm{Nb}-\mathrm{Ti}$ \\
\hline CP-K 60/78 & 0,12 & 0,8 & 2,2 & 0,04 & 0,015 & 0 & 1,2 & 0,2 & 0,005 & 1 & 0,15 \\
\hline CP-W 800 & 0,12 & 0,8 & 2,2 & 0,04 & 0,015 & 0 & 1,2 & 0,2 & 0,005 & 1 & 0,15 \\
\hline CP-W 1000 & 0,17 & 0,8 & 2,2 & 0,04 & 0,015 & 0 & 1,2 & 0,2 & 0,005 & 1 & 0,15 \\
\hline Dogal $600 \mathrm{CP}$ & 0,12 & 0,3 & 1,66 & 0,02 & 0,004 & 0,5 & 0,02 & 0 & 0 & 0 & 0 \\
\hline Dogal $800 \mathrm{CP}$ & 0,16 & 0,25 & 1,9 & 0,02 & 0,004 & 0,5 & 0,015 & 0 & 0 & 0 & 0 \\
\hline Litec 600CP & 0,18 & 0,8 & 2,2 & 0,02 & 0,004 & 0 & 2 & 0 & 0 & 1 & 0,15 \\
\hline Litec 800CP & 0,18 & 0,8 & 2,2 & 0,02 & 0,004 & 0 & 2 & 0 & 0 & 1 & 0,15 \\
\hline Litec 1000CP & 0,23 & 0,8 & 2,2 & 0,02 & 0,004 & 0 & 2 & 0 & 0 & 1,2 & 0,15 \\
\hline
\end{tabular}

Tablica VI. Właściwości mechaniczne wybranych stali complex CP

Table VI. Mechanical properties of selected complex-phase steels (CP)

\begin{tabular}{|c|c|c|c|c|c|}
\hline \multirow{2}{*}{ Stal } & \multicolumn{5}{|c|}{ Właściwości mechaniczne } \\
\hline & $\mathrm{R}_{\mathrm{e} \min }, \mathrm{MPa}$ & $\mathrm{R}_{\mathrm{e} \max }, \mathrm{MPa}$ & $\mathrm{R}_{\mathrm{m} \text { min }}, \mathrm{MPa}$ & $\mathrm{R}_{\mathrm{m} \max }, \mathrm{MPa}$ & $A_{80}, \%$ \\
\hline CP-K 60/78 & 600 & 700 & 780 & 940 & 10 \\
\hline CP-W 800 & 680 & 830 & 800 & 980 & 10 \\
\hline CP-W 1000 & 720 & 920 & 950 & 1130 & 10 \\
\hline Dogal $600 \mathrm{CP}$ & 350 & 500 & 600 & 750 & 16 \\
\hline Dogal $800 \mathrm{CP}$ & 500 & 700 & 780 & 950 & 10 \\
\hline Litec $600 \mathrm{CP}$ & 350 & 500 & 600 & - & 14 \\
\hline Litec $800 \mathrm{CP}$ & 500 & 700 & 780 & - & 8 \\
\hline Litec $1000 \mathrm{CP}$ & 700 & 900 & 980 & - & 5 \\
\hline
\end{tabular}

Tabela VII. Skład chemiczny wybranych stali TRIP

Table VII. Chemical composition of selected steels with TRIP

\begin{tabular}{|c|c|c|c|c|c|c|c|c|}
\hline \multirow{2}{*}{ Stal } & \multicolumn{8}{|c|}{ Skład chemiczny, \% } \\
\hline & $\mathrm{C}$ & $\mathrm{Si}$ & $\mathrm{Mn}$ & $P$ & $S$ & $\mathrm{Al}$ & Cr-Mo & $\mathrm{Nb}-\mathrm{Ti}$ \\
\hline Litec 700 TRIP & 0,32 & 0,8 & 2,5 & 0,02 & 0,004 & 2 & 0,6 & 0,2 \\
\hline Litec 800 TRIP & 0,32 & 0,8 & 2,5 & 0,02 & 0,004 & 2 & 0,6 & 0,2 \\
\hline RA-K 40/70 & 0,24 & 0,3 & 2 & 0,04 & 0,01 & 1,6 & 0,6 & 0,2 \\
\hline
\end{tabular}

Tablica VIII. Właściwości mechaniczne wybranych stali TRIP

Table VIII. Mechanical properties of selected steels with TRIP

\begin{tabular}{|c|c|c|c|c|c|}
\hline \multirow{2}{*}{ Stal } & \multicolumn{5}{|c|}{ Właściwości mechaniczne } \\
\hline & $\mathrm{R}_{\mathrm{e} \text { min }}, \mathrm{MPa}$ & $\mathrm{R}_{\mathrm{e} \max }, \mathrm{MPa}$ & $\mathrm{R}_{\mathrm{m} \min }, \mathrm{MPa}$ & $\mathrm{R}_{\mathrm{m} \max }, \mathrm{MPa}$ & $A_{80}, \%$ \\
\hline Litec 700 TRIP & 430 & 550 & 690 & - & 21 \\
\hline Litec 800 TRIP & 470 & 780 & 780 & - & 19 \\
\hline RA-K 40/70 & 410 & 510 & 690 & 790 & 23 \\
\hline
\end{tabular}




\section{Spawalność stali o wysokiej wytrzymałości}

Najtrudniejsze do spawania ze wszystkich stali AHSS są stale martenzytyczne. Strefa przyległa do strefy wpływu ciepła jest podatna na pęknięcia niezależnie od wstępnego podgrzania. Niemniej jednak stale martenzytyczne mogą być z powodzeniem spawane pod warunkiem, że zachowa się szczególne środki ostrożności oraz dostarczy wypełniacze, aby uniknąć pęknięć w konstrukcji spawanej. Blachy przeważnie są cienkie, natomiast równoważnik węgla zbliża się do niebezpiecznego poziomu. Powierzchnie spawane powinny być czyste i suche, żeby zapobiegać pęknięciom gorącym. Materiały spawalnicze powinny mieć zbliżone właściwości wytrzymałościowe do materiału łączonego oraz zapewniające niską zawartość wodoru w spoinie. Podczas spawania cienkich blach należy zmniejszyć energię liniową spawania. Ponieważ ciepło ze spoiny nie ma przestrzeni, by się rozproszyć, mogą powstać niskowytrzymałe pasma wokół złączy (nie można dopuścić do odpuszczania stali). Czas stygnięcia $t_{8 / 5}$ nie powinien przekraczać $4 \mathrm{~s}$. Konstrukcje ze stali MART powinny być projektowane z uwzględnieniem lokalizacji złączy, czyli tam, gdzie występują najmniejsze naprężenia. Głównym problemem jest wysoka twardość stali sięgająca ponad $300 \mathrm{HBV}$. W przeprowadzonych testach zderzeniowych okazało się, że spoina pochłania występujące siły bez pęknięć (spoina zgrzewana indukcyjnie prądami wysokiej częstotliwości HF-welding). Elementy konstrukcyjne wykonane ze stali martenzytycznej pomimo wysokiej wytrzymałości wykazują również dużą ciągliwość.

W spajaniu stali DP, CP stosuje się najczęściej punktowe zgrzewanie oporowe lub spawanie łukowe elektrodą metalową w osłonie gazu (GMA), spawanie nietopliwą elektrodą w osłonie gazów obojętnych (TIG), spawanie laserowe, plazmowe oraz ręczne spawanie łukowe elektrodą otuloną (MMA). Spoiny w złączach stali DP, CP mają o wiele większą wytrzymałość niż w złączach innych stali z grupy AHSS.

\section{Podsumowanie}

Stale o wysokiej wytrzymałości AHSS stanowią grupę stali nowej generacji o prostym składzie chemicznym, których mikrostruktura i właściwości kształtowane są w efekcie zaawansowanych procesów technologicznych powodujących umocnienie w wyniku przemian fazowych i odkształcenia plastycznego $\mathrm{w}$ warunkach różnych temperatur i różnych szybkości chłodzenia.

Ze względu na ich atrakcyjne właściwości mechaniczne, wyjątkową zdolność pochłaniania energii w czasie gwałtownych odkształceń stale o wysokiej wytrzymałości AHSS stanowią rozwojową grupę materiałów konstrukcyjnych, które w najbliższych latach powinny znaleźć bardzo szerokie zastosowanie w budowie maszyn i pojazdów.

Problemy spawalności i zgrzewalności tych stali stanowią jeden z ważniejszych problemów rozwoju ich zastosowań i dotyczą w pierwszym rzędzie opracowanie metod spajania zapewniających zachowanie mikrostruktury i właściwości stali w obszarze złącza.

\section{Literatura}

[1] Chatterjee S., Murugananth M., Bhadeshia H.K.D.H., ס-TRIP Steel. Materials Science and Technology, Issue 23/2007, s. 817-823.

[2] Lis A.K., Gajda B., Modelling of the DP and TRIP microstructure in the CMnAISi automotive steel, Jurnal of Achievements in Materials and Manufacturing Engineering, Vol. 15 Issue 1-2/2006, s. 127-134.

[3] Yi H.L., Lee K.Y., Bhadeshi H.K.D.H., Stabilisation of ferrite in hot rolled $\delta$-TRIP steel, Materials Science and Technology, Vol. 27, No. 2/2011/525-529.

[4] Senkara J., Współczesne stale karoseryjne dla przemysłu motoryzacyjnego i wytyczne technologiczne ich zgrzewania, Przegląd Spawalnictwa nr 11/2009, s. 3-7.

[5] Hofmann H., Mattissen D., Schaumann T. W., Advanced cold rolled steels for automotive applications, Steel Research International Issue 1/2009, s. 22-28.

[6] Prospekt AHSS, Material data sheet. Cold-rolled quenched \& tempered steel, boronalloyed, for cold forming and subsequent hot forming, (suitable for press hardening), Salzgitter Flachstahl 11-12/2005.

[7] Prospekt AHSS, Retained-austenite RA-K® For complex high-strength components, ThyssenKrupp Steel, 2008.
[8] Prospekt AHSS, SZMS1200 Martensitic grade, Salzgitter Flachstahl, 2006.

[9] Prospekt AHSS, TRIP (TRansformation Induced Plasticity) steels, Arcelor Mittal, 2010.

[10] Prospekt Docol AHSS, Advanced High Strength Steels for the automotive industry, SSAB Swedish Steel, 2010.

[11] Prospekt Docol AHSS, Docol DP/DL Zimnowalcowana stal dwufazowa, SSAB Swedish Steel, 2009.

[12] Prospekt Docol AHSS, Docol M Zimnowalcowana stal martenzytyczna, SSAB Swedish Steel, 2008.

[13] Prospekt Dogal AHSS, Dogal 600 i 780 CP Zaawansowane stale o wysokiej wytrzymałości, SSAB Swedish Steel 2008.

[14] Prospekt Dogal AHSS, Dogal 600 i 800 DP. Stal o extra i ultra wysokiej wytrzymałości, SSAB Swedish Steel, 2010.

[15] Prospekt Ruukki, Blachy walcowane na gorąco, w arkuszach i kręgach. Blachy pancerne Ramor, Ruukki, 2009.

[16] Prospekt Ruukki, Metal coated steel sheets and coils. Ultra high-strength formable steels Litec, 2009.

[17] Referencje Ruukki, Wysokowytrzymała stal Optim Ruukki - stal, którą się wybiera, Ruukki, 2010.

[18] Technical Transfer Dispatch, Advanced Vehicle Concept, 6/2001. 